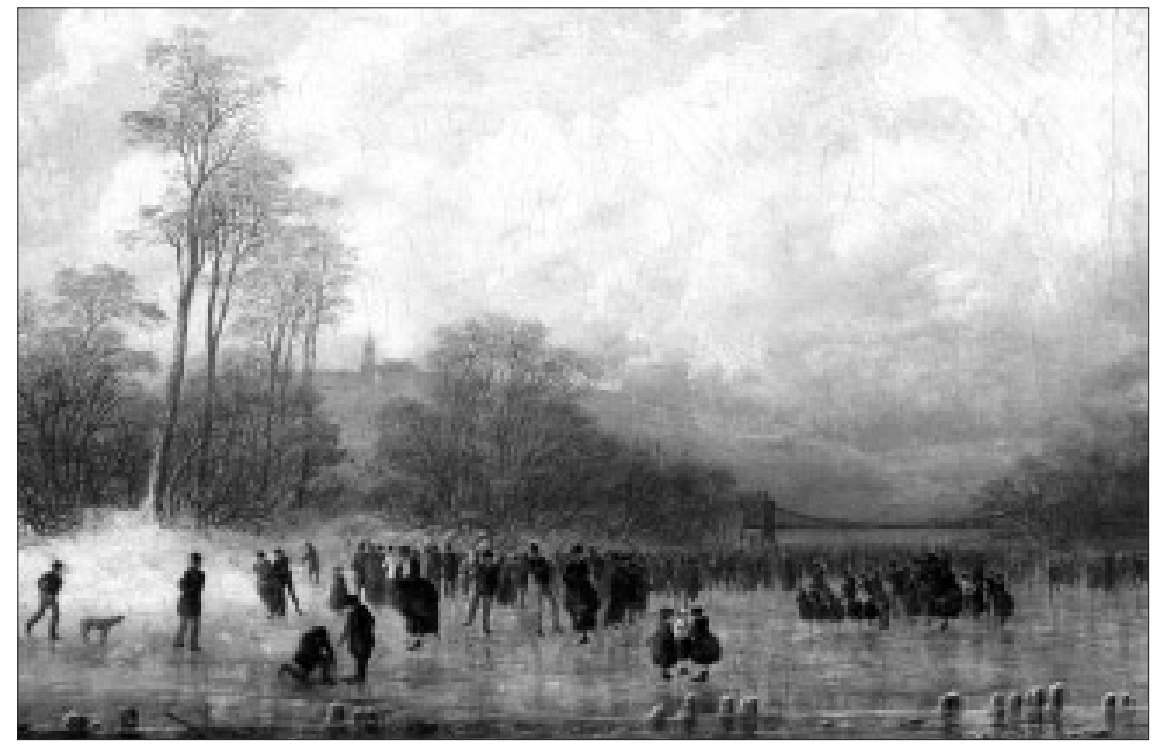

Skating-rink on the VItava River near Zofin Island, Prague. The Painting by Antonin Waldhauser (courtesy of Prague Municipal Museum) shows the river frozen. Such severe winters in the late Little Ice Age often preceeded catastrophic spring floods.

\section{Upper Pleistocene and Holocene Climatic Variations}

Prague, Czech Republic, 6-9 September 2000

A wide-ranging interdisciplinary meeting focused on 'Upper Pleistocene and Holocene Climatic Variations' was held in Prague. This event was organised by the Czech PAGES community under the auspices of the Institute of Geology of the Academy of Sciences of the Czech Republic and the Czech Geological Survey with support from the PAGES International Project Office in Bern. The conference dealt with long-term climatic and environmental changes with special reference to the glacial/interglacial cycles, as well as high-resolution short-term climatic variations. An assessment of anthropogenic impacts on the environment also belonged to the hot topics of the meeting.

Nearly one hundred climatologists, geologists, paleontologists, archeologists and other specialists from 19 countries joined the conference to discuss the problems of past climatic and environmental changes. Most of the contributions related to proxy archives preserved in the central and eastern European regions. The papers and posters presented covered a wide range of mostly continental paleoenvi-

\section{Correlation of Post- Glacial Climatic Events in the Arctic and Far-East Seas}

Moscow, Russia, 17-20 ApRIL, 2000

The main target of this workshop was to bring together Russian and foreign scientists involved in highresolution climatic and paleoceanographic studies in the Russian Arctic and Far East seas, to discuss new results and to make preliminary paleoclimatic correlations between different seas. The workshop was organized by Russian participants in IMAGES (M. Levitan, chairman; I. Murdmaa, M. Barash and E. Ivanova, members of the organizing committee), by the Shirshov Institute of Oceanology, Russain Academy of Sciences (RAS) and by the working group "Stratigraphy" of the Council of the World Ocean problems RAS; and was funded by IMAGES. One of the sessions was combined with the meeting of Russian-German Program KOMEX. In total, more than 40 scientists from several Russian and foreign institutions took part in the workshop sessions. 29 reports were presented, about one third of which contained results of co-operative Russian-French, Russian-American and Russian-German research.

The joint Russian-French team (Duplessy et al., Levitan et al.) presented millennium to century scale Holocene paleoceanographic records from the Barents and Kara Seas revealing the history of climate-related Atlantic water inflow (Fig. 1) and local events linked to sea level changes. A high resolution sedimentary record from the Russkaya Gavan' fjord (Novaya Zemlya) reflects migration of Shokal'sky glacier front related to climatic oscillations during the past millennium, including the Little Ice Age (Murdmaa et al.). I. Andreeva with co-authors (VNII Okeangeologiya, St. Petersburg) presented a detailed Late Holocene sedimentary record from the Kola Bay.

A series of reports by the KOMEX team from the Pacific Institute of 


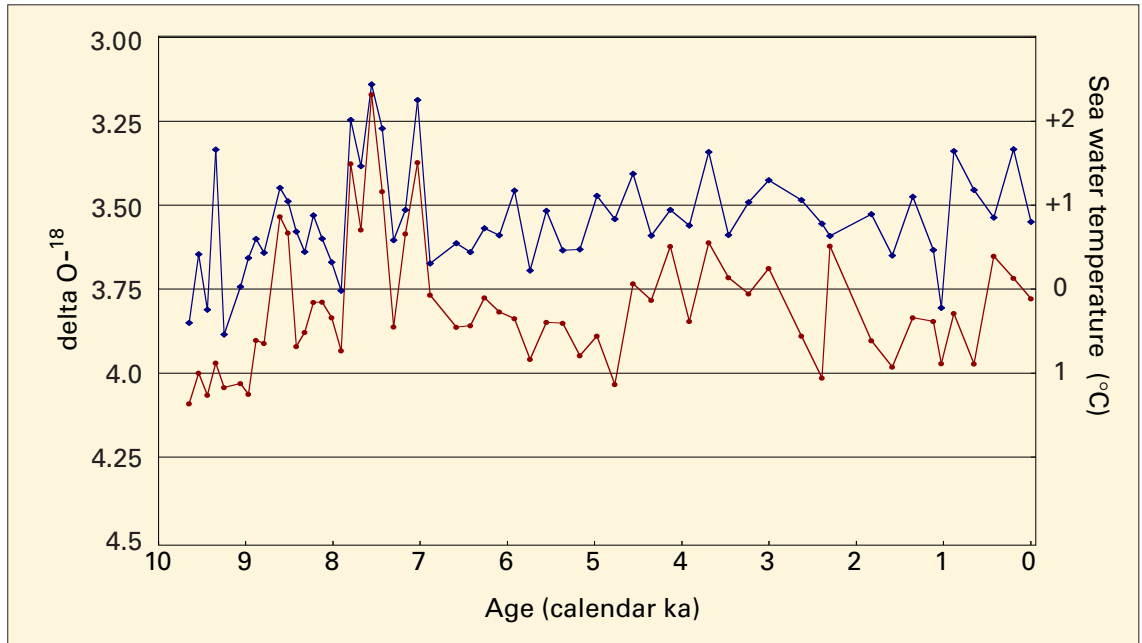

Oceanology (Vladivostok), Shirshov Institute of Oceanology (Moscow) and German institutions demonstrated new results on the Late Quaternary paleoceanography of the Sea of Okhotsk, including tephrochronology, micropaleontology, climatostratigraphy, stable isotopes, radiocarbon datings, ice-rafted debris, geochemical and mineralogical proxies (A. Abelman, A. Astakhov, M. Barash, N. Biebow, S. Gorbarenko, A. Kaiser, S. Kruglikova, A. Matul, R. Tiedemann and others).

Some authors attempted to correlate the major Holocene and Late Pleistocene paleoclimatic events in different Arctic and Far East areas (A. Svitoch, Y. Pavlidis, Y. Polyakova, and others) and link them with global changes and orbital signals. During the discussion, participants of the workshop noted considerable progress in the high-resolution Holocene paleoceanography and paleoclimatology of most Russian Arctic and Far East seas, except for the East Siberian Sea, which still represents a gap in our knowledge. New statistical approaches were also discussed (M.S.Barash and I.G.Yushina). All participants appreciated the fruitful discussion, and pointed to the importance of international co-operation in paleoceanographic studies within the IMAGES program.

Elena V. Ivanova, Michael A. Levitan, Ivan 0. MuRdMaA

Shirshov Institute of Oceanography,

Moscow, Russia

mlevitan@sio.rssi.ru

\section{IGBP Sediment Workshop}

BOULDER, USA, 25-27 SEPTEMBER, 2000

The IGBP Water Group held its first meeting in Stockholm (Feb 7-9, 2000), to discuss our knowledge of continental aquatic systems, how they have been impacted by climate and humans over the last 50 years, and how they may change over the next 50 years. Participants included members of the scientific steering committees of GCTE, LUCC, GAIM, PAGES, LOICZ, and BAHC. This follow-up workshop concentrated on anthropogenic influences on the supply and flux of sediment along hydrological pathways on a global scale. Attendees representing the PAGES Ecosystem Processes and Human Dimensions Focus included John Dearing, Aleksey Sidorchuk, Des Walling and Bob Wasson.

The key question addressed at the workshop was 'What is the flux of sediment to the coast, presently, and what was it in the past and under pristine conditions?' Other issues discussed included 'Global Change and Sensitive Areas' and 'Data and Typology'. The group recognized that because river systems evolve through time modern river systems are strongly influenced by past conditions within the watershed as well as modern conditions. Understanding the discharge of sediment across a broad time-scale will allow us to make better predictions for the future. Analysis of historic river data was shown to provide high resolution information about
Figure 1: Local $\delta^{18} \mathrm{O}$ changes versus age in the planktonic species Neogloboquadrina pachyderma left coiling and the benthic species Elphidium clavatum in core ASV 880 (795 $55^{\prime} 5$ N, 4708'2 E, water depth 388 $m)$. The approximate temperature scale has been established assuming that the core top reflects modern conditions and that the water temperature decreases by $1^{\circ} \mathrm{C}$ when the foraminifer $\delta^{18} \mathrm{O}$ value increases by $0.25 \%$ [Reference: Duplessy et al. (in press) Holocene paleoceanography of the Northern Barents Sea and variations of the northward heat transport by the Atlantic Ocean, Boreas.]

the recent trajectories of sediment flux driven by climate, land use and reservoir construction. Discussion about the role of paleo-reconstruction focused on using sedimentary archives to provide baseline data in pre-disturbance times and recent trajectories of change. Numerous existing examples from lake sediment, reservoir, floodplain, deltaic and nearshore marine sequences testify to the ability for paleo-methods to contribute strongly to this area across a range of spatial and temporal scales.

The workshop concluded that the IGBP community should strive to:

- Develop globally integrated sediment databases and budgets (error checking, harmonization, verification, temporal compatibility),

- Develop community-wide sediment models (both numerical and conceptual) and analysis,

- Understand the geographical differences in sediment fluxes (regional analysis, high vs. low, humid vs. arid, tropical vs. temperate, temperature effects)

- Determine the impacts of sediment fluxes on broader Earth and human systems.

The full report on which this summary is based is available from James Syvitski (James.Syvitski@colorado.edu), and papers from the Boulder meeting will be published as a special issue of Global and Planetary Change.

\section{John Dearing}

University of Liverpool, UK j.dearing@liverpool.ac.uk 